\title{
The type material and the enamel structure of Villanyia exilis KRETZOI, 1956 (Arvicolidae, Rodentia)
}

\author{
David F. MAYHEW
}

Received: 24 November 2008

Accepted: 20 January 2009

MAYHEW D. F. The type material and the enamel structure of Villanyia exilis KRETZOI, 1956 (Arvicolidae, Rodentia). Acta zoologica cracoviensia, 52A(1-2): 81-94.

Abstract. Re-examination of the two teeth constituting the original type and genotype material of Villanyia exilis KRETZOI, 1956 from Villány-5, Hungary, indicates that subsequently published descriptions need revision. The tooth selected as the lectotype of Villanyia exilis by RABEDER (1981) is considered here to belong to Clethrionomys kretzoii (KOWALSKI, 1958). The second specimen, with morphology in accordance with the original description of Kretzoi, is considered to represent the characters of Villanyia exilis. In order to stabilise the nomenclature in accordance with current usage an application has been made to the International Commission on Zoological Nomenclature. The fine structure of the enamel of Villanyia exilis as defined above is described for the first time, based on a tooth from the Late Villanyian of Osztramos-3, Hungary. It demonstrates a simple grade of arvicolid evolution. This enamel type differs substantially from the enamel structure of material from Rębielice Królewskie, Poland, which was originally identified as Mimomys (Villanyia) exilis by KOWALSKI (1960), but considered here to be referable to the genus Borsodia. The generic name Villanyia has been applied widely in the literature to various other taxa, mainly species of extinct rooted lagurine voles which are currently referred to the genus Borsodia (JÁNOSSY \& VAN DER MEULEN, 1975). It is proposed to limit the use of the genus name Villanyia to the latest part of a lineage of uncertain origin which became extinct close to the Villanyian/Biharian boundary.

Key words: Voles, Pliocene, Pleistocene, taxonomy, evolution, Europe, enamel structure.

David F. MAYHEW, Natuurhistorischmuseum Rotterdam, Westzeedijk, 345, 3015AA Rotterdam. Nationaal Natuurhistorisch Museum Naturalis, Darwinweg 2, 2333 CR, Leiden, the Netherlands.

E-mail: dfm1@stcatharinescollege.org

\section{INTRODUCTION}

The new genus and species Villanyia exilis was described from Villány-5, Hungary, by KRETZOI (1956) on the basis of two lower first molars. The description was brief with no illustrations. The first illustrations of the two specimens were provided by RABEDER (1981), who designated one of the teeth as the lectotype of $V$. exilis and the other the holotype of a new species Cseria ultima.

TERZEA (1991) described abundant material of $V$. exilis from Betfia-XIII and demonstrated that the morphology of the lower first molar corresponded not to the specimen from Villány-5 selected 
as the lectotype by RABEDER (1981), but to the other specimen. She figured this second specimen as being the "lectotype". Subsequent authors have adopted the description of TERZEA (1991) as the correct definition of the characters of $V$. exilis. Since the original description, the genus name $\mathrm{Vil}$ lanyia has also been widely used in the literature for a diversity of taxa. Various authors referred teeth from a number of Pliocene and Pleistocene localities to $V$. exilis (e.g. KOWALSKI 1960, from Rębielice Królewskie, Poland). Some of these referrals were made on unclear grounds, and require reassessment on the basis of recent knowledge.

During a visit to the Hungarian Geological Institute, Budapest the type material was cleaned and re-examined. This revealed discrepancies in respect of previously published descriptions. As there is no material other than the type of $V$. exilis known from Villány-5, a tooth of $V$. exilis found in the samples from the fissure filling Osztramos-3, Hungary (considered close in age to Villány-5) was studied to investigate the enamel structure (Schmelzmuster). This enables a broader discussion of the definition of Villanyia and its place in the Arvicolidae. Finally, this enamel structure is compared with that of a tooth from the assemblage from Rębielice Królewskie, Poland, previously identified as Mimomys (Villanyia) exilis, but considered here to be in fact referable to Borsodia.

A b b r e viations:

PAS - Institute of Systematics \& Evolution of Animals, Polish Academy of Sciences, Kraków;

GIH - Hungarian Geological Institute, Budapest;

NHMUS - Hungarian Natural History Museum, Budapest.

\section{SYSTEMATIC SECTION: REDESCRIPTION OF TYPE MATERIAL}

The terminology follows RABEDER (1981) and TESAKOV (2004). Crown height and enamel free area heights are measured perpendicular to the wear surface. The base of the crown is considered to be the base of the enamel of the posterior labial re-entrant fold. Measurements are in $\mathrm{mm}$.

Genus Villanyia KRETZOI, 1956

1956 Villanyia exilis gen. et sp. nov. (partim) - KRETZOI: 118.

1960 nec Villanyia exilis - KOWALSKI: 184 figs 6 a-f, 7 a-d. (=Borsodia)

1965 nec Mimomys (Villanyia) sp. - ALEXANDROVA: 101, 106, fig. 13 a,b.

1970 Mimomys (Villanyia) sp. (partim) - SUKHOV: 61, plate 8, figs 108-110. (assigned with some reservation).

1970 nec Mimomys (Villanyia) praehungaricus - SUKHOV: plate 10, figs 131-143 (a mixture of species, some specimens Borsodia).

1976 nec Villanyia - ALEXANDROVA: 46 et ff. (= Borsodia).

1977 Villanyia (partim) - GROMOV \& POLYAKOV: 215 etff. (only type, rest are lagurids referrable to Borsodia).

1980 nec Villanyia -ZAZHIGIN: 98 etff. (all species described as Villanyia appear to be Borsodia).

1981 Cseria proopsia-RABEDER: 56.

1981 Cseria opsia - RABEDER: 59.

1991 nec Villanyia kowalskii - TERZEA: 91 (=Borsodia).

1991 nec Villanyia veterior - TERZEA: 91 (=Borsodia).

1994 nec Villanyia - REKOVETS: fig. 31 etc.

2001 Villanyia - KOWALSKI: 291.

2005 nec Villanyia - ERBAJEVA: 58 et ff. (Villanyia eleonorae and Villanyia klochnevi=Borsodia).

2006 nec Villanyia - ERBAJEVA et al.: 115 et ff. (= Borsodia).

2008 nec Villanyia fangchangensis - ZHANG et al.: 165 (considered referrable to tribe Clethrionomyini). 


\section{Villanyia exilis KRETZOI, 1956}

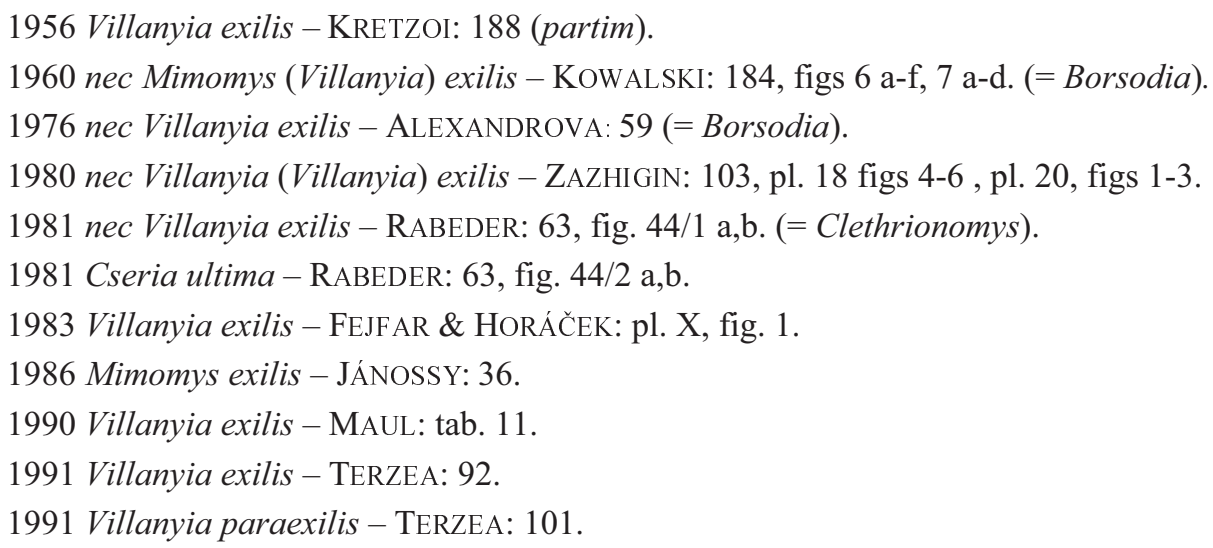

$\mathrm{M}$ e a s u r e m e $n \mathrm{t}$ s. Crown height $(\mathrm{CH})=1.20$; Length of wear surface $(\mathrm{L})=2.13$; Width of wear surface $(\mathrm{W})=0.85$; Anterosinuid $(\mathrm{ASD})=0.78$; Hyposinuid $(\mathrm{HSD})=0.75$; Hyposinulid $($ HSLD $)=0.35$; Hyposinuid/Hyposinulid index $($ HH-index $)=0.82$; Relative anteroconid length $(\mathrm{A} / \mathrm{L})=45 \%$.

$\mathrm{D}$ e s c r i p t i o $\mathrm{n}$. This is a very small tooth, with a relatively low crown, and very low enamel free areas. The anterior loop is relatively long, corresponding precisely to KRETZOI's description "high" when viewed with the occlusal surface axis orientated vertically. There is a slight trace of a Mimomys ridge visible on the labial side, although this is not clearly to be seen in the occlusal view. The angles are rounded, the lingual re-entrant angles especially so. On the occlusal surface, T2 and T3 are very broadly confluent. They are separated from T1, which is confluent with the posterior loop. There is no trace of crown cement. The enamel is thick relative to the size of the tooth, and is similar in thickness on the anterior and posterior margins of the triangles. The posterior enamel is worn more, giving the impression of being thinner than the anterior enamel. However, as demonstrated in section III, it is actually thicker.

D i s c u s s i o n. This tooth is similar to the description and drawing of RABEDER (1981, p. 63, Abb. 44, fig. 2.), although slightly wider, and with T2 and T3 slightly more confluent. This tooth corresponds to the original type description of $V$. exilis by KRETZOI (1956) as already recognised by TERZEA (1991, p. 91, last paragraph) in her thorough description of Villanyia from the Betfia-XIII, Roumania, fissure deposit. The interpretation of this material is considered later in the general discussion.

RABEDER (1981, p. 63) selected this tooth as the holotype and only specimen of a new species Cseria ultima, in view of the similarity to other material assigned to Cseria. Later however, CARLS and RABEDER (1988, p. 213) withdrew this, stating: "the separation of the lectotype described as Cseria ultima RABEDER, 1981 does not seem to be justified”. The name Villanyia exilis KRETZOI, 1956 has priority over Cseria ultima RABEDER, 1981. 


\section{Genus Clethrionomys TILESIUS, 1850}

Note: Current proposals (CARLETON et al. 2003; CARLETON and MUSSER 2005) would make Clethrionomys TILESIUS, 1850 a junior synonym of Myodes PALLAS, 1811. However, currently the genus name Clethrionomys is still in widespread use. As the present paper concerns Villanyia, in order not to confuse different nomenclature issues, Clethrionomys is used here on the understanding that revision to Myodes may be made in future.

\section{Clethrionomys kretzoii (KOWALSKI, 1958)}

1958 Dolomys kretzoii - KOWALSKI: 27, fig. 15.

1981 Villanyia exilis - RABEDER: 63, fig. 1.

1981 Clethrionomys kretzoii-RABEDER: 257.

1988 Clethrionomys kretzoii-CARLS and RABEDER: 148.

1996 Clethrionomys kretzoii - TESAKOV: 542.

1998 Clethrionomys kretzoii-TESAKOV: 112.

M a t e r i a 1. Specimen GIH V-12702 Vt95 \#1 m1 (dext.) from Villány-5.

F i g u r e s. Fig. 1 d-f.

$\mathrm{M}$ e a s u r e m e $\mathrm{n} t \mathrm{~s}$. Crown height $(\mathrm{CH})=2.83$; Length of wear surface $(\mathrm{L})=2.10$; Basal length $(\mathrm{BL})=2.25$; Width of wear surface $(\mathrm{W})=0.76$; Anterosinuid $(\mathrm{ASD})=2.35$; Hyposinuid $(H S D)=2.15$; Hyposinulid $(H S L D)=2.41$; Relative anteroconid length $(A / L) 43 \%$.

$\mathrm{D}$ e s c r i p t i o $\mathrm{n}$. This is a relatively high crowned tooth. It is damaged, probably by digestion by a predator. The enamel crown is completely formed, roots are just beginning to form. The dentine triangles on the wear surface are broadly communicating. The enamel appears approximately equally thick on anterior and posterior sides of the triangles. The anteroconid has prominent external triangles, and a well defined, slightly angular, anterior loop. The BSA3 is directed backwards. The tips of BRA1 and BRA2 curve anteriorly.

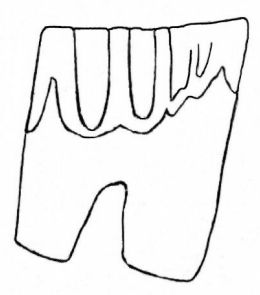

a

$\mathrm{d}$

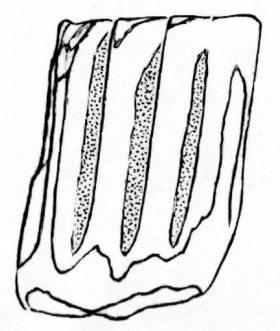

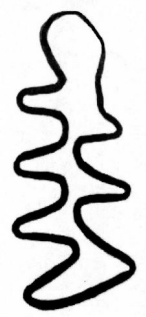

b

e

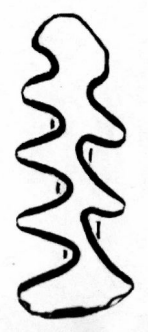

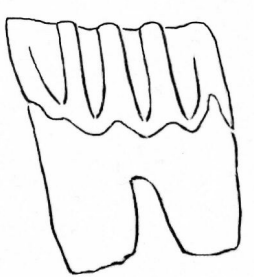

C

f

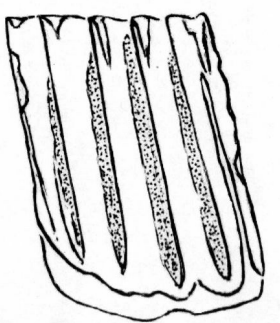

Fig. 1. a-c-GIH V-12702 Vt95 \# 2 lower right m1 Villanyia exilis KRETZOI, 1956; d-f-GIH V-12702 Vt95 \#1: lower right $\mathrm{m} 1$ Clethrionomys kretzoii (KOWALSKI, 1958). Scale mark $1 \mathrm{~mm}$. 
Thorough cleaning of the tooth (removal of wax) and study under alcohol and acetone indicates that the anterior and posterior enamel free areas are high. The anterosinuid extends at least $2.35 \mathrm{~mm}$ but appears not to reach the wear surface. The hyposinuid is at least $2.15 \mathrm{~mm}$ high: the rest of the back of the tooth is damaged so the true height cannot be determined. The hyposinulid appears to be closed at a height of $2.41 \mathrm{~mm}$. Crown cementum was visible in most of the re-entrants. These observations differ substantially from those of previous authors.

D i s c u s s i o n. This tooth was redescribed and first figured by RABEDER (1981, Abb. 44, fig. 1), who selected it as the lectotype of $V$. exilis. However, he recorded the enamel free areas as low, whereas they are high, and he found crown cement to be absent, whereas it is present. This changes the interpretation of the tooth. Furthermore, this tooth does not correspond well to the type description of KRETZOI (1956) viz. (translation from German original) "The characters of Mimomys and Prometheomys combined in a very small-sized type (m1- length 2.0-2.1 mm), with confluent prism pairs and wide rounded re-entrant angles behind the high Mimomys anterior loop (without fold or islet)". As is obvious from the illustrations given here, this description applies much more accurately to specimen $\mathrm{Vt} 95 \# 2$.

The configuration of the tooth Vt95\#1 is unusual and clearly it does not belong to the same taxon as Vt95\#2. It has been attempted to locate similar teeth in the literature and in museum collections. The closest found have been Ungaromys dehmi CARLS \& RABEDER, 1988 (observed in Osztramos-3 material, NHMUS collection) and "Dolomys" kretzoii KOWALSKI, 1958 (currently referred to Clethrionomys see below) from the type locality Kadzielnia, Poland (PAS collection, type and topotype material seen) and from Ozstramos-3 (NHMUS collection).

Compared with $U$. dehmi from Ozstramos-3, Vt95 \#1 differs in having more rounded lingual re-entrant angles, and a larger more rounded and posteriorly directed BSA3. BRA 1 and BRA2 are more forwardly directed and crown cement is present (considered absent in Ungaromys). In lateral view the lower first molar of $U$. dehmi has a leading edge which is concave, whereas in Vt95\#1 it is almost straight. In $U$. dehmi the enamel free areas (especially the hyposinulid) are lower than in Vt95\#1.

C. kretzoii is abundant in the assemblage from Ozstramos-3. Vt95\#1 falls within the range of size and morphology of this sample.

Compared with the type of "Dolomys" kretzoii from Kadzielnia, Vt95\#1 differs in occlusal view in having a smaller, less rounded, anterior lobe. However, this may be at least partly due to damage and dissolution of enamel in Vt95 \#1 at the top of the tooth, seen by the greater basal length. Further, the confluence between T1 and T2 is less in Vt95 \#1 and between T2 and T3 greater in Vt95 \#1. The overall configuration of re-entrant folds and salient angles (allowing for damage) is quite similar. The type material of "Dolomys" kretzoii consists of a fragmentary mandible with $\mathrm{m} 1$ and $\mathrm{m} 2$. The overall height of the enamel free areas of the $\mathrm{m} 1$ cannot be determined accurately. However, it appears that all do not reach the wear surface. Two isolated $\mathrm{m} 1$ provide information on the heights of the dentine tracts (Table I).

Table I

Measurements of "Dolomys" kretzoii KOWALSKI, 1958 from type locality Kadzielnia, Poland

\begin{tabular}{|c|c|c|c|c|c|c|c||}
\hline \hline Specimen & CH & L & W & ASD & HSD & HSLD & RAL \\
\hline \hline Type: PAS ISEZ MF/40/1 & 1.72 & 2.20 & 0.86 & 1.19 & 1.20 & 1.20 & $48 \%$ \\
\hline NHMUS Kretzoi colln \#1 & 2.94 & 2.05 & 0.91 & 2.21 & 2.22 & 2.13 & $49 \%$ \\
\hline NHMUS Kretzoi colln \#2 & 2.36 & 2.27 & 0.94 & 1.81 & 2.05 & 1.67 & $47 \%$ \\
\hline
\end{tabular}


The overall size of these teeth agrees with Vt95 \#1, and the heights of the enamel free areas are slightly lower.

"Dolomys" kretzoii is currently considered to belong to the genus Clethrionomys. Abundant material referred to $C$. kretzoii has been described by CARLS and RABEDER (1988). The overall similarity in appearance of Vt95\#1 to Clethrionomys has also previously independently been noted by TERZEA (1991, p. 91) and by TESAKOV (2004, p. 173). The new details observed, i.e. high enamel free areas, and presence of some crown cement, strongly support this allocation. The relatively confluent triangles and small amount of crown cement are characteristic of teeth of a young animal. Following the scheme of TESAKOV (1996) the tooth can be assigned to C. kretzoii.

However, it can be noted that from Villány-5, another Clethrionomys species (C. solus KRETZOI, 1956, later renamed C. intrans KRETZOI, 1958) is recorded. The type lower first molar of C. solus (GIH V12703 Vt96) is of different appearance to C. kretzoii from Kadzielnia. It has rounded, more typically Clethrionomys-like salient and re-entrant angles, and is larger. This might imply that either two species of Clethrionomys coexisted, or that the Villány-5 assemblage is heterogeneous in geological age, or that there is a high degree of variability in C. kretzoii (see CARLS and RABEDER 1988).

In view of the above information and conclusions about the type material of $V$. exilis KRETZOI, 1956, and as the proposals of RABEDER (1981) have not been followed by subsequent authors, an application has been made to the International Commission for Zoological Nomenclature to consider void taxonomic acts between the original publication and TERZEA (1991) in the interests of stability.

\section{FINE STRUCTURE ("SCHMELZMUSTER”) OF THE ENAMEL OF VILLANYIA EXILIS FROM OSZTRAMOS-3, HUNGARY}

VON KOENIGSWALD (1980, p. 60-61) described the enamel fine structure of three teeth said to belong to Villanyia. The first was of $V$. steklovi ZAZHIGIN, 1980 from Beteke, northern Kazahkstan. Currently this species is referred to the genus Borsodia (TESAKOV 2004). The second came according to the text description from Rębielice, Poland (incorrectly labelled in the figure 62 as coming from Węże, Poland). Following examination of the Rębielice material, this is considered to belong to Borsodia. The third tooth was from Kizikha, Western Siberia, Russia, and is considered to be an advanced Borsodia species. Therefore it is concluded that the fine structure of the enamel of $V$. exilis, as defined here, has not been previously documented.

A lower first molar considered to belong to $V$. exilis was selected by the author for study by SEM from previously unidentified material from the locality Osztramos-3, Hungary (collection of Hungarian Natural History Museum, locality here considered to be somewhat older than Villány-5). The tooth was prepared according to the method of VON KOENIGSWALD (1980) using 2n HCL for 5 seconds to etch the enamel, and examined using the SEM facility of Naturalis, Leiden. The enamel pattern studied was approximately $1.5 \mathrm{~mm}$ above the crown base. The description below follows the terminology of VON KOENIGSWALD (1980, 1997).

The enamel pattern of $V$. exilis (see Fig. 2) appears relatively simple, lacking the very clear differentiation of enamel types usually seen in Gelasian and Early Pleistocene Mimomys or Borsodia species. In occlusal section mainly radial enamel is to be seen. There are very small patches of discrete lamellar enamel (= uniserial Hunter-Schreger bands, HSB) in the salient angles (Fig. 2B, 2E). On the lingual side, the anterior enamel of the triangles and posterior loop ("leading edge") consists of two layers of radial enamel: an external layer and an internal layer in which the prisms are orientated more obliquely (ca. 45 degrees) to the surface with little interprismatic substance (Fig. 2C). The anterior enamel of the buccal part of the posterior loop and T2 consists of a single layer of radial enamel in which the great majority of the crystallites are orientated perpendicularly to the occlusal plane with little interprismatic substance. The rear margin of the posterior loop appears to consist 

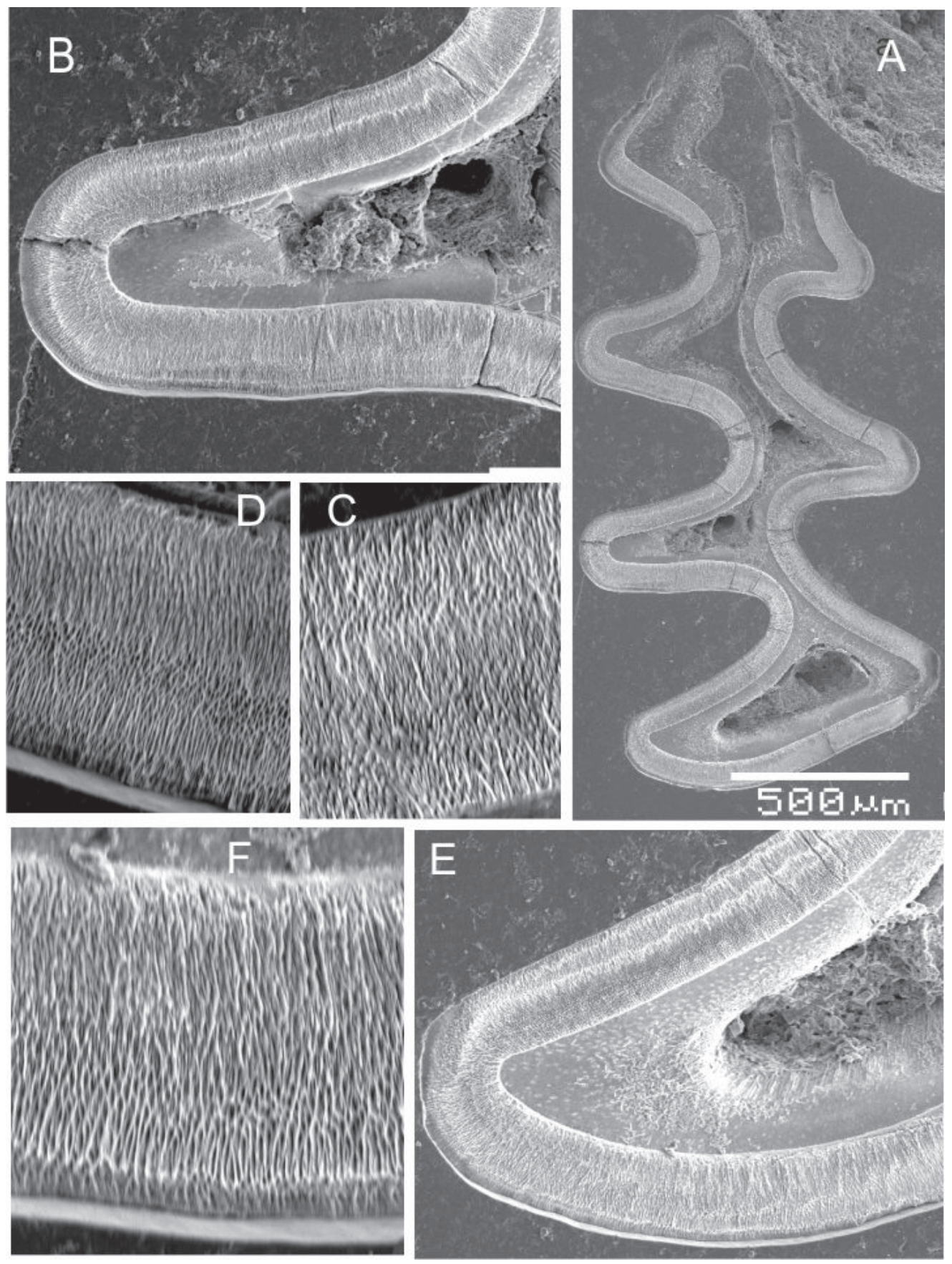

Fig. 2. Enamel fine structure of Villanyia exilis from Osztramoz-3, Hungary. Material: lower m1, NHMUS Budapest. A whole tooth in cross section approximately $1.5 \mathrm{~mm}$ above crown base: the enamel consists almost entirely of various layers of radial enamel; B - second lingual salient angle demonstrating enamel thicker on the posterior margin; C - enlargement of radial enamel on anterior face of second lingual salient angle: $\mathrm{D}$ - enlargement of radial enamel on the posterior face of the second lingual salient angle; E - posterior loop with radial enamel and very limited development of lamellar enamel at the salient angle; $\mathrm{F}$ - enlargement of enamel of posterior loop to show concentric layers of radial enamel. (SEM Naturalis, Leiden). 
only of radial enamel. The rear margins ("trailing edge") of the lingual triangles consist of radial enamel orientated into concentric layers by small changes in the direction of the crystallites. The rear margin of the buccal salients consists of radial enamel with towards the rear side a small area of change in orientation of the crystallites which, although very limited in extent, could be possibly considered primitive tangential enamel.

The ground section as used for the SEM photographs (Fig. 2A) shows that the enamel is slightly differentiated, with the posterior enamel of T1, T2 and T3 being about $10 \%$ thicker than the anterior. This result is of interest, because photographs of the wear surface of the same tooth before preparation gave the appearance of the enamel being slightly thicker on the anterior margins of the triangles. It suggests that only preparation of ground sections allows objective comparisons of this feature in arvicolids. The small degree of differentiation observed, and the simplicity of the enamel structure, is in accordance with previous descriptions (e.g. TERZEA 1991) considering the enamel undifferentiated.

The relatively simple pattern described here separates $V$. exilis from most other arvicolids dating from the Late Villanyian/Early Biharian, which have by then acquired more diverse enamel configurations including clear tangential and lamellar enamel on the leading and trailing faces of the triangles. Broadly similar simple enamel configurations have been described by VON KOENIGSWALD (1980) in primitive arvicolids including Ungaromys, Stachomys, Ellobius and particularly Prometheomys. Particularly interesting is the lack of tangential enamel in $V$. exilis except possibly for small areas on the buccal salients.

A photograph of a similar enamel pattern in a tooth from Stranzendorf-F, Austria, was described under the name Cseria opsia by RABEDER (1981, pl. 10, fig. 4). This has radial enamel, with no tangential enamel, and only small areas of lamellar enamel. It appears to differ from the $\mathrm{m} 1$ of $V$. exilis from Osztramos-3 in that the enamel is shown as much thicker on the leading edge, but this is due mainly to the image concerning the BSA1 of the upper M2, where the relative thickness is atypical (RABEDER, pers. comm.) The definition of the species C. opsia (RABEDER 1981, p. 59) states "enamel not or only weakly differentiated". TESAKOV (2004) proposed that the species Cseria opsia and Cseria proopsia may belong instead to the genus Villanyia. The study of RABEDER (1981) and examination of the original material from Stranzendorf, Austria, on which the taxa Cseria opsia and Cseria proopsia were based support this. Therefore they are provisionally included in the synonymy of Villanyia given in section II.

\section{FINE STRUCTURE (“SCHMELZMUSTER”) OF THE ENAMEL OF “MIMOMYS (VILLANYIA) EXILIS” FROM RĘBIELICE (= BORSODIA)}

A lower first molar from the assemblage from Rębielice (collection PAS) originally referred to Mimomys (Villanyia) exilis by KOWALSKI (1960) has been examined. The enamel pattern (Fig. 3) consists largely of radial enamel. Discrete lamellar enamel extends around the salient angles as a layer between inner and outer radial enamel and extends some way along the anterior enamel. Significant areas of incipient tangential enamel occur at the back of the posterior loop and on the rear margins of the lingual triangles and the lingual side of the anterior loop. In this lower first molar the enamel is $5-10 \%$ thicker on the anterior margins of the triangles. This description is in accordance with that of VON KOENIGSWALD (1980 p. 60-61, fig. 62, under the name " $V$. exilis"), and is considered here to document a very early stage of evolution of the genus Borsodia. Similar material has been described from Ripa Skortselskaya as Borsodia cf. steklovi (ZAZHIGIN, 1980) by TESAKOV (2004). As noted above, the enamel differentiation in Villanyia exilis is also rather small, but in the opposite sense.

The material from Deutsch Altenburg described by RABEDER (1981) under the name Cseria carnuntina appears very similar to Borsodia from Rębielice. The relationship between Borsodia from Rębielice and $V$. exilis requires further clarification. 

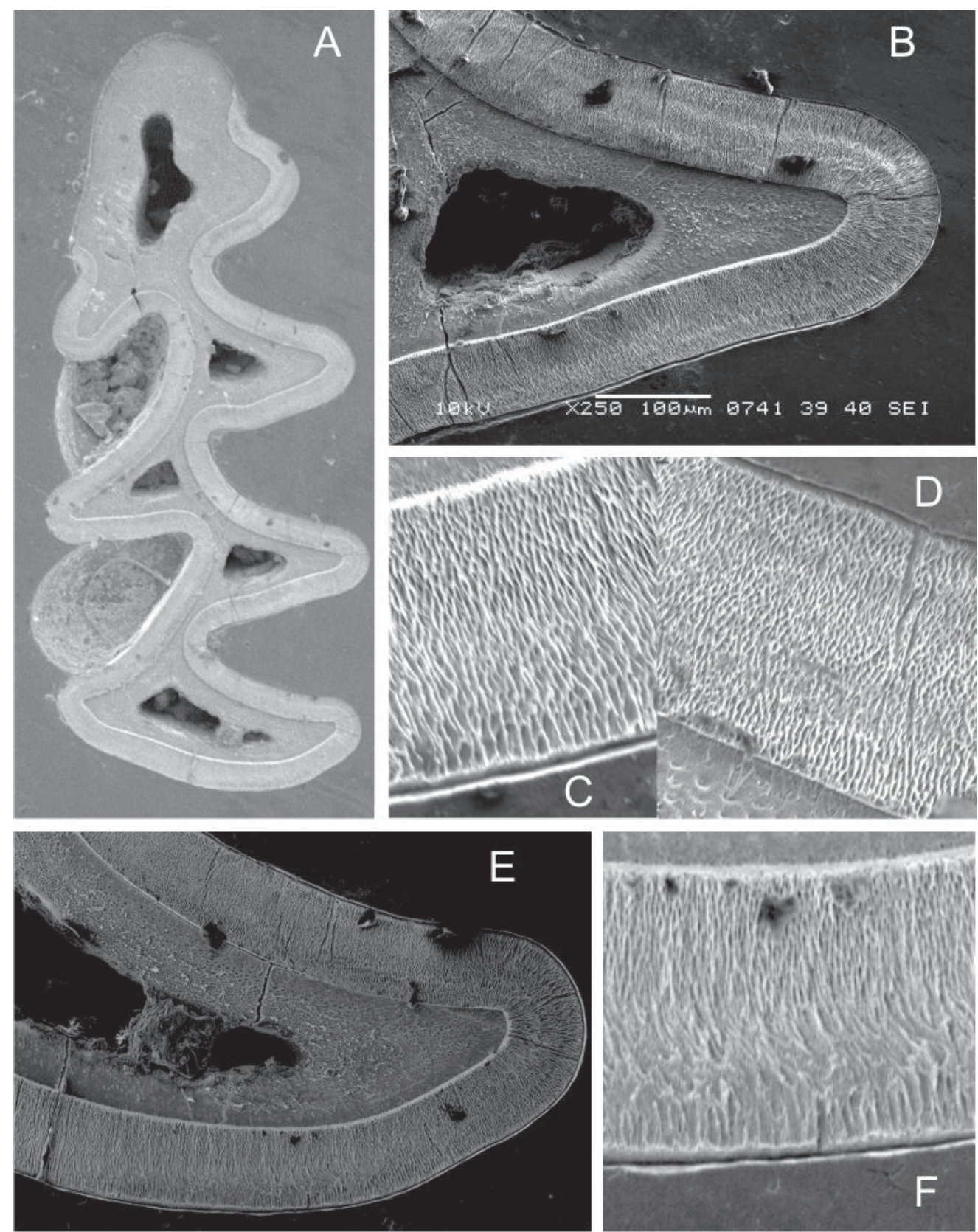

Fig. 3. The enamel fine structure of Borsodia from Rebielice Królewskie 1, Poland (previously known under Mimomys (Villanyia) exilis). Material: lower m1, PAS Kraków. A - whole tooth in cross section ca $1.5 \mathrm{~mm}$ above crown base: the enamel consist mainly of radial enamel with weak development of primitive tangential enamel on the posterior margins of the lingual salients and the posterior loop, and some lamellar enamel at the salients and anterior margins; B - second lingual salient angle demonstrating unequal (reverse differentiated) enamel thickness; $\mathrm{C}$ - enlargement of posterior enamel of second lingual salient, consisting of an internal layer of radial enamel and an external layer of primitive tangential enamel; D - enlargement of anterior enamel on second salient angle consisting of radial enamel; E - posterior loop with weak development of lamellar enamel at the salient angle and primitive tangential enamel on the posterior side; F - enlargement of posterior loop rear enamel demonstrating an internal layer of radial enamel and an external layer of primitive tangential enamel. (SEM Naturalis, Leiden). 


\section{GENERAL DISCUSSION}

Since the original brief description, lacking an illustration and type designation, there has been unclarity about the definition and the affinities of $V$. exilis. Assemblages found at various localities particularly in the Eastern European countries have been described in the literature as containing various species of the genus Villanyia: e.g. by KOWALSKI (1960, material from Rębielice identified as Mimomys (Villanyia) exilis followed by e.g. AlEXANDROVA (1965), SuKHOV (1970), GROMOV and POLYAKOV (1977), ZAZHIGIN (1980), TERZEA (1991), REKOVETS (1994), REKOVETS and DEMA (2001) and ERBAJEVA (2005). This approach was also followed by ZHANG et al. (2008). However, in view of the new information presented here concerning the genotype material, much of the material called Villanyia in these publications seems better separated into the extinct lagurine vole genus Borsodia (JÁNOSSY \& VAN DER MEULEN, 1975).

Several publications have described material which appears to be the same taxon as the tooth (VT95\#2) taken here to represent $V$. exilis. For example, FEJFAR and HORÁČEK (1983, pl. X, fig. 1) illustrated a lower first molar from Včelare 3, Slovakia. SALA et al. (1994) illustrate specimens from the fissure filling of Rivoli Veronese, Italy. $V$. exilis is also recorded from Kadzielnia and Kamyk, Poland (NADACHOWSKI 1998): examination of this material confirms that teeth in approximately the same stage of wear are very similar in morphology to VT95\#2. Further, $V$. exilis has been described from level 11d of Kozarnika Cave, Bulgaria (POPOV \& MARINSKA 2007). From Hungary, as well as the single tooth from Villány-5, V. exilis is recorded (JÁNOSSY 1986) as present in the assemblage from Osztramos-3 (collection NHMUS Budapest): further material from this locality including a maxilla and several mandibles was determined recently by the author whilst in Budapest.

The publication of TERZEA (1991) on Villanyia from Betfia-XIII describes to modern standards relatively abundant material which clearly belongs to the same species as Vt 95\#2. All the teeth in the dentition are described, so her work is the best reference point for $V$. exilis: however, the conclusions require some comments. TERZEA (1991) separated $V$. exilis from Betfia-XIII as a distinct temporal subspecies, $V$. exilis crisiensis, said to be more primitive than $V$. exilis exilis from Villány-5. However, in a following paper (TERZEA 1996) it was suggested that the fauna of Villány-5 was not later, but earlier, than Betfia-XIII. Therefore separation into (temporal) subspecies is here regarded as abandoned. Fig. $3 \mathrm{C}$ of TERZEA (1991) is stated to be the lectotype of $V$. exilis ("d'apres RABEDER, 1981, fig. 44/2"). However, this drawing is actually RABEDER's type of Cseria ultima, and the figure legend can be understood only in relation to the comments of TERZEA (1991 p. 91, last paragraph) concerning change of lectotype.

TERZEA (1991) also described the new species $V$. paraexilis from Betfia-XIII, the new species $V$. kowalskii from Rębielice Królewskie and proposed to use the name $V$. veterior KRETZOI, 1969 for a second supposed species from this locality. The lectotypes from Rębielice were designated by reference to figures from KOWALSKI (1960). According to her analysis of Villanyia there were two parallel lineages through the Late Pliocene and Early Pleistocene, an idea suggested originally by KOWALSKI (1960) in view of observed variability. The lineage $V$. kowalskii-V. paraexilis was supposed to be more primitive, and the other $V$. veterior- $V$. exilis was supposed to be more progressive.

Now $V$. exilis crisiensis from Betfia-XIII is described as lacking a Mimomys fold on the anterior loop of the lower $\mathrm{m} 1$, whereas in V. paraexilis also from Betfia-XIII this fold is supposed to be present. However, on VT95\#2 V. exilis from Villány-5, there is actually a slight indication of the Mimomys fold on the side of the tooth, i.e. it is not absent. Therefore it is considered more probable that the presence or absence of a Mimomys fold, or its persistence in the crown, is not a sufficient character to justify recognising two coexistent species of Villanyia. A similar situation is known from the large Mimomys from West Runton, UK, split by HINTON (1926) into M. majori, M. intermedius, and M. savini using a similar approach, but currently treated by most workers as a single species with variability in this character. $V$. paraexilis TERZEA, 1991 is therefore considered a junior synonym of V. exilis KRETZOI, 1956. 
Examination of the original material from Rębielice assigned to Mimomys (Villanyia) exilis by KOWALSKI (1960) (and to V. kowalskii and V. veterior by TERZEA 1991), as well as further material from this locality (PAS collection), indicates high variability in respect of the Mimomys ridge and configuration of the anterior loop. These teeth are of small size and have enamel thicker on the leading edges, apparently not noticed by previous authors. The dentine of the triangles of the $\mathrm{m} 1$ is hardly confluent even in worn teeth. The enamel free areas are very low. The angles are pointed. There is no crown cement. It is considered probable that these teeth represent a very early stage in the evolution of Borsodia, similar to Borsodia cf. steklovi (ZAZHIGIN, 1980) from Ripa Skortselskaya as described in TESAKOV (2004). In particular the upper first molars demonstrate a typical Borsodia morphology. This may imply that the locality Rębielice 1 is somewhat older than previously realised. However, further work is needed to clarify this, and indeed how many different taxa are present in the fauna.

The very limited material from Kadzielnia (PAS collection) previously considered to belong to Villanyia includes teeth with closed dentine fields, resembling Borsodia, as well as other teeth with confluent dentine fields and apparently undifferentiated enamel which resemble $V$. exilis. The material appears to be heterogeneous.

A single worn tooth from Kamyk (PAS collection) has confluent dentine fields and an enamel configuration as in $V$. exilis. The material described from Betfia-XIII (TERZEA 1991) is indistinguishable from that seen by the author from Osztramos-3.

From Russia, the genus Villanyia (as defined here) is known from the Urals (unpublished, TESAKOV, pers. comm.). Some teeth described as Villanyia from Akkulaevo (SUKHOV 1970, tab. 8, figs. 108-110) and from Simbugino (SUKHOV 1977, tab. 51, figs. 11,12) appear to be attributable to this genus. TESAKOV (2004) lists these occurrences under the name $V$. veterior, and records early Borsodia species from the same deposits.

Recently the genus name Villanyia has been used broadly to include the subgenera Villanyia, Borsodia, Cseria, Kulundomys and Shamaromys covering several lines of arvicolid evolution (REKOVETS \& DEMA 2001; DEMA \& REKOVETS 2004). This proposal seems to extend the definition of Villanyia (a genus based on a late Early Pleistocene single tooth, of unusually simple structure) too widely in morphology and time. Synapomorphies uniting these five diverse subgenera are not obvious, and the heterogeneity of the type material of $V$. exilis as demonstrated here was apparently not recognised.

A similar broad view of the genus Villanyia has been proposed in a redefinition by ZHANG et al. (2008), but this was not based on direct observation of the genotype material or reference to the important work of TERZEA (1991). Their new species Villanyia fanchangensis is considered on the basis of their illustrations to be probably referable to the clade of Clethrionomine voles. The mandible of " $V$. fanchangensis" differs markedly from that of $V$. exilis from Ozstramos-3 (pers. obs.).

The origin and relationships of " $V$. exilis" have been debated in the literature, but this discussion has frequently been based on other fossil assemblages which are considered here to belong to the extinct lagurid vole genus Borsodia. The dentition of $V$. exilis from Villány-5, Osztramos-3 and Betfia XIII is relatively low crowned and primitive, with confluences in the dentine fields and simple enamel structure. It has therefore been thought to be a burrowing species, possibly related to recent genera Ellobius, Prometheomys or Hyperacrius. RABEDER (1981) and CARLS and RABEDER (1988) suggested a relationship with Cseria and/or Ungaromys. As conceived here, Villanyia is distinct in morphology from Borsodia, and restricted to a single lineage commencing in the Early Villanyian and most prominently represented in East European faunas of the later part of the Villanyian and earliest Biharian. The distribution of this form appears to have been restricted mainly to East Europe. It was of small size, and possibly of burrowing habit. The earliest representatives appear to be from Simbugino, and the latest occurrence at Kamyk. 


\section{CONCLUSIONS}

It is proposed that, of the original 2 types, Specimen \#2 is considered the genotype and type of V. exilis KRETZOI, 1956, and specimen \#1 is identified as C. kretzoii (KOWALSKI, 1958). It is proposed that taxonomic acts subsequent to the original publication and prior to TERZEA (1991) are discarded in the interests of stability. A proposal to this effect is submitted to the International Commission on Zoological Nomenclature.

Much of the material previously identified in the literature as Villanyia is considered to belong to other taxa, notably Borsodia. It is proposed that the genus Villanyia should be restricted to the later part of an isolated lineage which evolved rather little during the Late Pliocene and Early Pleistocene.

The enamel structure of $V$. exilis, described here for the first time on the basis of a tooth from Osztramos-3, Hungary, consists largely of radial enamel, with very little tangential or lamellar enamel. This is the primitive arvicolid condition, although secondary simplification cannot be ruled out. This enamel pattern differs substantially from that of a tooth from Rębielice, Poland, from the assemblage described as Mimomys (Villanyia) exilis by KOWALSKI (1960), and here referred to Borsodia sp.

A c k n o w l e d g e m e n t s. I thank Prof. Laszlo KoRDos (Hungarian Geological Institute, Budapest) and Prof. Adam NADACHOWSKI (Polish Academy of Sciences, Kraków) for access to collections in their care, hospitality, and essential discussions. I am grateful to Dr. Mihaly GASPARIK and the management of the Hungarian National Natural History Museum for hosting my visits and providing material for analysis. Part of this work was supported by a travel grant under the EEC Synthesys program. SEM facilities were provided by Naturalis, Leiden. I thank Dr. Alexey TESAKOV (Geological Institute, Academy of Sciences, Moscow) for generously providing additional information and for discussions, Dr. Lutz MAUL for valuable comments on the manuscript, and Dr. Lars VAN DEN HOEK OSTENDE (Naturalis, Leiden), Dr. Federica MARCOLINI (University of Rome) and Dr. Francien DIELEMAN for assistance and advice.

\section{REFERENCES}

AlEXANDROVA L. P. 1965. Iskopaemye polevki (Rodentia, Microtinae) iz eopleistotsena iuzhnoi Moldavii i iugo-zapadnoi Ukrainy [Fossil Eopleistocene Voles (Rodentia, Microtinae) of Southern Moldavia and South-western Ukraine]. [In:] INQUA Congress - Stratigraphic Value of Anthropogene Faunas of small mammals. Geological Institute, Academy of Sciences USSR, Moscow, pp. 98-110. (In Russian).

ALEXANDROVA L. P. 1976. Gryzuny antropogena evropeiskoï chasti SSSR [Rodents of the Anthropogene of the European Part of the USSR]. Transactions of the Geological Institute, Academy of Sciences of USSR, 29: 1-98. (In Russian).

Carleton M. D., Musser G. G. 2005. Subfamily Arvicolinae. [In:] D. E. Wilson, D. M. ReEder (eds) Mammal Species of the World (third edition). Vol. 2. Johns Hopkins University Press, Baltimore, pp. 956-1039.

Carleton M. D., Musser G. G., Pavlinov L. Ya. 2003. Myodes Pallas, 1811, is the valid name for the genus of red-backed voles. [In:] A. AVERIANOV, N. ABRAMSON (eds) - Proceedings, International Conference Systematics, Phylogeny and Paleontology of small mammals. Zoological Institute, Russian Academy of Sciences, Moscow, pp. 96-98.

CARLS N., RABEDER G. 1988. Die Arvicoliden (Rodentia, Mammalia) aus dem Ältest-Pleistozän von Schernfeld (Bayern). Beiträge zur Paläontologie von Österreich, 14: 123-237.

DEMA L., REKOVETS L. 2004. Morfosistematichni osnovi evoliutsi rodu Villanyia (Arvicolidae, Rodentia) [Morphosystematic fundamentals of evolution in the genus Villanyia (Arvicolidae, Rodentia)]. Visnyk L'viv Univ. Biol. Series, 38: 152-156. (In Ukrainian).

ERBAJEVA M. A. 2005. Vimershie polevki Zabaikaliya i severnogo Kitaya (Arvicolinae, Rodentia). [Fossil voles of Transbaikal and Northern China]. Proceedings, Zoological Institute St. Petersburg, 306: 55-71. (In Russian).

ERBa.JeVa M. A., AleXeeva N., KhenZykhenova F. 2006. Review of the Pliocene-Pleistocene arvicolids of the Baikalian region. Palaeontographica Abt. A, 278: 113-123. 
FEJFAR O., HORÁČEK I. 1983. Zur Entwicklung der Kleinsäugerfaunen im Villányium und Alt-Biharium auf dem Gebiet der ČSSR. Schriftenreihe geologische Wissenschaft, 19/20: 111-207.

Gromov I. M., PolyaKov I. Ya. 1977. Voles (Microtinae). Fauna of the USSR. Mammals, Vol. 3, No. 8 . Smithsonian Institute, Oxonian Press, New Delhi. (Translation 1992).

Hinton M. A. C. 1926. Monograph of the voles and lemmings. Vol. 1. British Museum (Natural History), London, $488 \mathrm{pp}$.

JÁNOSSY D. 1986. Pleistocene vertebrate faunas of Hungary. Akadémiai Kaidó and Elsevier, Budapest and Amsterdam, $209 \mathrm{pp}$.

JÁNOSSY D., VAN DER MEULEN A. J. 1975. On Mimomys (Rodentia) from Osztramos-3, North Hungary. Proceedings Koninklijke Akademie Wetenschap Series B, 78(5): 381-391.

VON KOENIGSWALD W. 1980. Schmelzstruktur und Morphologie in den Molaren der Arvicolidae (Rodentia). Abhandlungen Senckenberg naturforschung Gesellschaft, 539: 1-129.

VON KOENIGSWALD W. 1997. Evolutionary trends in the differentiation of mammalian enamel ultrastructure. [In:] W. VON KOENIGSWALD, P. M. SANDER (eds) - Tooth enamel microstructure. Balkema, Rotterdam, pp. 203-235.

KOWALSKI K. 1958. An early Pleistocene Fauna of small mammals from the Kadzielnia hill in Kielce (Poland). Acta Palae ontologica Polonica, 3: 1-47.

KOWALSKI K. 1960. Pliocene Insectivores and Rodents from Rębielice Królewskie (Poland). Acta zoologica cracoviensia, 5: 155-200.

KOWALSKI K. 2001. Pleistocene Rodents of Europe. Folia Quaternaria, 72: 1-389.

KOWALSKI K., NADACHOWSKI A. 1990. Review of fossil arvicolid faunas of Poland. [In:] O. FEJFAR, W.-D. HEINRICH (eds) - International Symposium on the Evolution, Phylogeny and Biostratigraphy of Arvicolids. Geological Survey, Prague, pp.: 297-304.

KRETZOI M. 1956. Die Altpleistozänen Wirbeltierfaunen des Villanyer Gebirges. Geologica Hungarica, series Paleontologica, 27: 1-264.

KRETZOI M. 1958. New names for Arvicolid homonyms. Annales historico-naturales musei naturalis Hungarici, 50: 55-58.

KretzoI M. 1969. Skizze einer Arvicoliden Phylogenie-Stand - Stand 1969. Vertebrata Hungarica Musei Historico-Naturalis Hungarici, XI: 155-193.

MAUL L. 1990. Überblick über die unterpleistozänen Kleinsäugerfaunen Europas. Quartärpaläontologie, 8: 153-191.

MAUL L., MARKOVA A. 2007. Similarity and regional differences in Quaternary arvicolid evolution in Central and Eastern Europe. Quaternary International, 160: 81-99.

NADACHOWSKI A. 1998. Faunal succession of small mammal assemblages at the Pliocene-Pleistocene boundary in Poland. Mededelingen Nederlands Instituut voor Toegepaste Geowetenschappen TNO, 60: 281-286.

POPOV V. V., MARINSKA M. 2007. An almost one million year long (Early to Late Pleistocene) small mammal succession from the archaeological layers of Kozarnika Cave in Northern Bulgaria. Courier ForschungsInstitut Senckenberg, 259: 79-92.

RABEDER G. 1981. Die Arvicoliden (Rodentia, Mammalia) aus dem Pliozän und dem älteren Pleistozän von Niederösterreich. Beiträge zur Paläontologie von Österreich, 8: 1-373.

REKOVETS L. I. 1994. Melkie mlekopitayushchie antropogena uiga vostochnoi Evropy [Small mammals of Anthropogene of South Eastern Europe]. Naukova Dumka, National Academy of Sciences Ukraine, Institute of Zoology, Kiev, 372 pp. (In Russian with English summary).

REKOVETS L. I., DEMA L. P. 2001. Nadvidovye sistematicheskie kategorii roda Villanyia KRETZOI, 1956 (Rodentia, Mammalia) [Superspecific systematic ranks of the genus Villanyia KRETZOI, 1956 (Rodentia, Mammalia)] National Academy of Sciences of Ukraine, Kiev. Proceeding of the National Natural History Museum of Ukraine, pp.: 106-112. (In Russian).

SAla B., MASINI F., TORRE D. 1994. Villanyian arvicolids from Rivoli Veronese, a karst fissure in the Adige valley. Bolletino della Societa Paleontologica Italiana, 33: 3-11.

SUKHOV V. P. 1970. Pozdnepliotsenovye melkie mlekopitayuschie Akkulaevskogo mestonachozhdeniya v Bashkiri [Late Pliocene small mammals from the locality Akkulaevo in Bashkiria]. Nauka, Moscow, 93 pp. (In Russian).

SUKHOV V. P. 1977. Melkie pozvonochnie [Smaller vertebrates]. [In:] G. I. GORETSKY (ed) - Fauna i flora Simbugino. Nauka, Moscow, 121-139. (In Russian).

TERZEA E. 1991. Le genre Villanyia. Travaux Institute Spéologie Emile Racovitza, XXX: 89-105.

TERZEA E. 1996. Biochronology of the Pleistocene deposits at Betfia (Bihor, Romania). Acta zoologica cracoviensia, 39: 531-540.

TESAKOV A. S. 1996. Evolution of bank voles (Clethrionomys, Arvicolinae) in the late Pliocene and early Pleistocene of eastern Europe. Acta zoologica cracoviensia, 39: 554-547.

TESAKOV A. S. 1998. Voles of the Tegelen fauna. Mededelingen Nederlands Instituut voor Toegepaste Geowetenschappen TNO, 60: 79-134. 
TESAKOV A. S. 2004. Biostratigrafiya srednego pliotsena-eopleistotsena vostochnoi Evropy [Biostratigraphy of the Middle Pliocene-Eopleistocene of Eastern Europe]. Transactions of the Geological Institute Russian Academy of Sciences, 554, Moscow, Nauka Press, 247 pp. (In Russian with English summary).

TOPACHEVSKY V. A., SKORIK A. F. 1977. Gryzuny rannetamanskoi fauny Tiligulskogo razreza [Rodents of the Early Tamansk fauna and Tiligul sections]. Kiev, Naukova Dumka, 249 pp. (In Russian with English summary).

ZAZHIGIN V. S. 1980. Gryzuny pozdnego pliotsena i antropogena uiga zapadnoi Sibiri [Late Pliocene and Anthropogene Rodents of the South of Western Siberia]. Transactions of the Geological Institute Academy of Sciences USSR, 339, Moscow Nauka Press, 155 pp. (In Russian with English summary).

ZHANG Y., KAWAMURA Y., Jin C. 2008. A new species of the extinct vole Villanyia from Renzidong Cave, Anhui, East China, with discussion on related species from China and Transbaikalia. Quaternary International, 179: 163-170. 